\title{
Chromosome 22q11.2 microdeletion in monozygotic twins with discordant phenotype and deletion size
}

\author{
Ashutosh Halder ${ }^{1 *}$, Manish Jain ${ }^{1}$, Isha Chaudhary ${ }^{1}$ and Binuja Varma ${ }^{2}$
}

\begin{abstract}
We report on a pair of male monozygotic twins with 22q11.2 microdeletion, discordant phenotype and discordant deletion size. The second twin had findings suggestive of DiGeorge syndrome, while the first twin had milder anomalies without any cardiac malformation. The second twin had presented with intractable convulsion, cyanosis and cardiovascular failure in the fourth week of life and expired on the sixth week of life, whereas the first twin had some characteristic facial appearance with developmental delay but no other signs of the 22q11.2 microdeletion syndrome including cardiovascular malformation. The fluorescence in situ hybridization (FISH) analysis had shown a microdeletion on the chromosome 22q11.2 in both twins. The interphase FISH did not find any evidence for the mosaicism. The genomic DNA microarray analysis, using HumanCytoSNP-12 BeadChip (Illumina), was identical between the twins except different size of deletion of 22q11.2. The zygosity using HumanCytoSNP-12 BeadChip (Illumina) microarray analysis suggested monozygosity. This observation indicates that altered size of the deletion may be the underlying etiology for the discordance in phenotype in monozygotic twins. We think early post zygotic events (mitotic non-allelic homologous recombination) could have been played a role in the alteration of 22q11.2 deletion size and, thus phenotypic variability in the monozygotic twins.
\end{abstract}

\section{Introduction}

The 22q11.2 microdeletion syndrome is the most common microdeletion syndrome with an estimated incidence of one in 4000 to 6,000 live births and mostly spontaneous [1-3]. The 22q11.2 microdeletion is found in patients with DiGeorge syndrome, Velocardiofacial syndrome and Conotruncal anomaly face syndrome [4]. It is characterized by wide spectrum of clinical manifestations, including craniofacial (cleft palate, velopharyngeal insufficiency), thymic and parathyroid defects as well as cardiovascular (outflow tract and aortic arch) malformations [5]. Almost all the cases result from a common deletion of the chromosome 22q11.2 locus. The FISH is the prime method for diagnosis of this microdeletion syndrome.

Several reports have mentioned phenotypic discordance between the monozygotic twins with 22q11.2 microdeletion [6-12]. No definite mechanism has been

\footnotetext{
* Correspondence: ashutoshhalder@gmail.com

'Department of Reproductive Biology, All India Institute of Medical Sciences, New Delhi, India

Full list of author information is available at the end of the article
}

demonstrated until now for the discordant phenotype. However, somatic mosaicism, post zygotic second hit or environmental effects have been proposed. We report on a pair of monozygotic male twins with $22 \mathrm{q} 11.2$ microdeletion and discordant phenotype resulting from altered deletion size.

\section{Case Reports}

\section{Second Twin}

A four weeks old baby boy was presented in the pediatric emergency with recurrent intractable seizures, central cyanosis and unconsciousness. During evaluation in the emergency, baby had an attack of cardiopulmonary arrest. The baby was revived and kept on the ventilator. On physical examination tachycardia \& systolic murmur was noted. ECG was suggestive of ventricular tachycardia. X-ray examination of chest showed cardiomegaly. Repeated blood calcium level showed hypocalcemia, despite calcium and vitamin $\mathrm{D}$. The baby was suspected to have DiGeorge Syndrome with major cardiac malformation and cardiac failure. Blood sample was sent for 22q11.2 microdeletion study. The baby was expired on 
sixth week of life despite intensive care, including artificial life support assistance. There was no history of antenatal complications. The baby was fine for first three weeks of life. The baby was developed abnormal movements of all limbs (tonic-clonic type) along with up slanting of eyes in fourth week of life. The baby had intermittent seizures initially but became intractable in few days before referral to our hospital.

Since the baby had findings strongly suggestive of DiGeorge syndrome, the FISH study to detect a possible deletion in the critical 22q11.2 region was done using DNA probe specific for the 22q11.2 locus. The FISH was done using $1 \mathrm{ml}$ of blood $(0.5 \mathrm{ml}$ heparinized for the metaphase and $0.5 \mathrm{ml}$ EDTA for the interphase cells) obtained from the patient as described before [13-15]. In brief, the metaphase spreads were prepared from the phytohaemagglutinin stimulated human peripheral blood lymphocytes using standard cytogenetic technique. The interphase spreads were prepared from the blood nucleated cells (both twins), buccal cells (first twins only) and urinary cells (first twins only) after washing in phosphate buffer saline solution three times before 30 minutes of hypotonic treatment $(50 \mathrm{mMol}$ $\mathrm{KCL})$ and the fixation in methanol:acetic acid solution (3:1 ratio). The cells (interphase \& metaphase) were resuspended in $100 \mathrm{ul}$ of fresh fixative. Approximately 20 ul cell suspensions were used to prepare a slide (interphase or metaphase). FISH probe was made from the PAC clone (RP5-882J5 obtained from Uniba Biologia,
Italy, by curtsy of Prof. M Rocchi). The PAC clone was grown in LB broth, DNA extracted and about one ug DNA labeled with red flurochrome (Cy3) by nick translation method. About $300 \mathrm{ng}$ labeled probe per slide was used for FISH. The FISH analysis was carried out using Olympus BX51 microscope with epifluorescence attachment and image was captured through the Applied Spectral Imaging system (Israel). The FISH result showed $94 \%$ interphase nuclei and 100\% metaphase nuclei with hemizygous 22q11.2 deletion (Table 1; Figure 1). Normal control cases displayed two signals in approximately $98 \%$ interphase and 100\% metaphase nuclei.

\section{First Twin}

The first twin was referred to our hospital (pediatrics outpatient department) at 13 months of age due to dysmorphic features \& developmental delay and later to our department for the 22q11.2 microdeletion study. He had few episodes of upper respiratory infections, swallowing difficulties and one episode of convulsion in the first year of life. His developmental milestones were delayed, unable to speak or walk even at 13 months of age. The baby had broad nose, square shaped tip of nose, thin upper lip, wide philtrum, folded pinna, low set ears and mild hypertelorism, telecanthus \& squint (Figure 2A). His weight and length was normal however, he had relatively small head (head circumference was 41 $\mathrm{cm}$ at 13 months i.e., below fifth percentile). His cry had

Table 1 is showing detailed FISH results of twins

\begin{tabular}{|c|c|c|c|c|}
\hline Parameters & $22 q 11.2$ one signal & $22 q 11.2$ two signals & $22 q 11.2$ three/four signals & Remarks* \\
\hline \multicolumn{5}{|l|}{ Second Twin } \\
\hline Uncultured Blood & 940 & 055 & 005 & 94\% hemizygous deletion \\
\hline \multicolumn{5}{|l|}{ Cultured Blood } \\
\hline Metaphase & 010 & 000 & 000 & $100 \%$ hemizygous deletion \\
\hline Interphase & 120 & 005 & 001 & 95\% hemizygous deletion \\
\hline \multicolumn{5}{|l|}{ First Twin } \\
\hline Uncultured Blood & 850 & 072 & 003 & $92 \%$ hemizygous deletion \\
\hline \multicolumn{5}{|l|}{ Cultured Blood } \\
\hline Metaphase & 025 & 000 & 000 & $100 \%$ hemizygous deletion \\
\hline Interphase & 110 & 006 & 001 & 94\% hemizygous deletion \\
\hline Buccal cells & 051 & 003 & 000 & 94.4\% hemizygous deletion \\
\hline Urinary Cells & 025 & 002 & 000 & 92.6\% hemizygous deletion \\
\hline \multicolumn{5}{|l|}{ Mother } \\
\hline \multicolumn{5}{|l|}{ Cultured Blood } \\
\hline Metaphase & 000 & 010 & 000 & Normal dizygous 22q11.2 locus \\
\hline Interphase & 007 & 500 & 002 & $98.2 \%$ normal dizygous \\
\hline \multicolumn{5}{|l|}{ Father } \\
\hline \multicolumn{5}{|l|}{ Cultured Blood } \\
\hline Metaphase & 000 & 010 & 000 & Normal dizygous 22q11.2 locus \\
\hline Interphase & 008 & 500 & 003 & 97.8\% normal dizygous \\
\hline
\end{tabular}

${ }^{*}$ In general < 10\% mosaicism with 22q11.2 interphase FISH seems clinically insignificant 


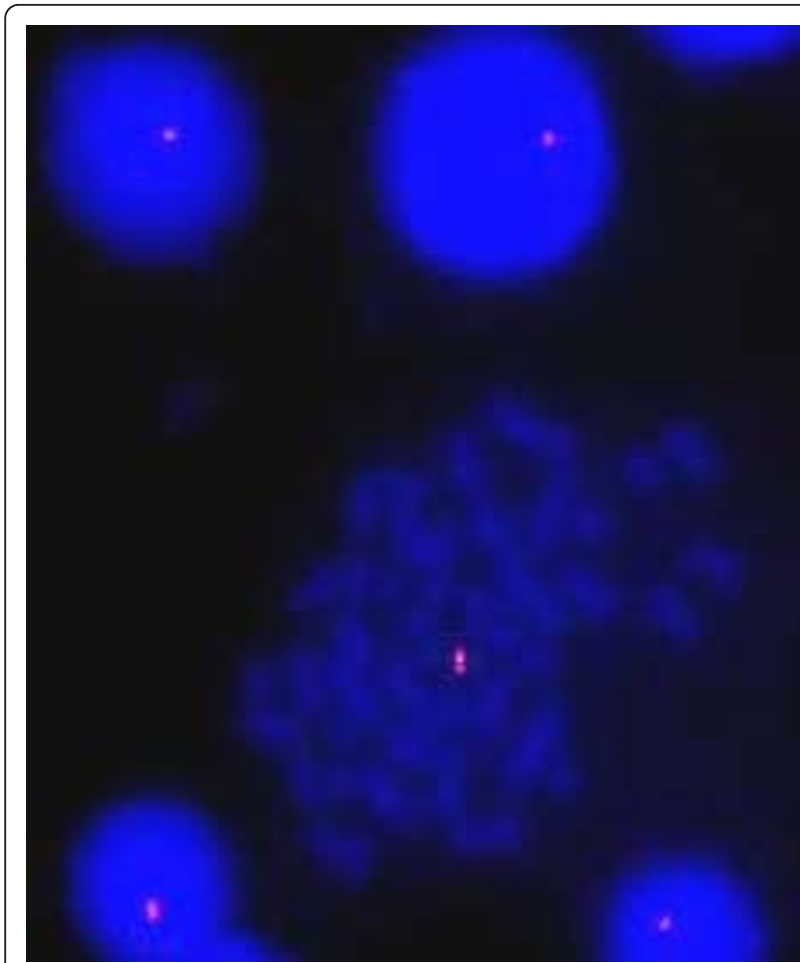

Figure 1 is showing $22 q 11.2 \mathrm{FISH}$ with deletion on interphase and metaphase cells obtained from peripheral blood lymphocyte culture.

nasal intonation however there was no obvious cleft palate. Ophthalmologic \& auditory examination revealed no abnormality. Extensive cardiovascular work up including the echocardiography was normal. MRI scan of head and brain was also normal. There was no hypocalcemia. Conventional cytogenetics from the lymphocyte culture was normal. Since the patient had co-twin with 22q11.2 microdeletion and he has some findings suggestive of 22q11.2 microdeletion syndrome the FISH study to detect a possible deletion in the critical $22 \mathrm{q} 11.2$ region was done. The interphase FISH result showed $92 \%$ nuclei with hemizygous deletion for the $22 \mathrm{q} 11.2$ locus (Figure 2B) in the blood (mesodermal origin), 94.4\% in the buccal cells (ectodermal origin) and 92.6\% in the urinary cells (mainly endodermal origin). FISH on metaphase spread picked up deletion in all the 25 metaphases studied (Table 1; Figure 2C).

The twins were born to a 25 year-old mother (first pregnancy) at term by cesarean section delivery in a private nursing home. The second twin was $2400 \mathrm{gm}$ at birth whereas his brother (the first twin) was $2700 \mathrm{gm}$ at birth. Records of the length and head circumference at birth were not available. There was no similar problem in the family in either parental side. Parents were screened for the 22q11.2 microdeletion and were found negative for the deletion.

\section{Genomic DNA Microarray Analysis}

DNA microarray study was carried out to find out reason for discordance using HumanCytoSNP-12 BeadChip (Illumina). The DNA was extracted from $250 \mathrm{uL}$ of stored EDTA blood sample using Qiagen micro kit. The DNA quality and quantity was checked using agarose gel \& Nanodrop. The concentration of DNA was normalized to $50 \mathrm{ng} / \mathrm{ul}$. About $200 \mathrm{ng}$ of DNA was used for the microarray study. The DNA sample denatured and isothermally amplified in an overnight step (whole-genome amplification uniformly increases the amount of the DNA sample by several thousand-fold without introducing large amounts of amplification bias). The amplified product was then fragmented using controlled enzymatic process using end-point fragmentation. After an isopropanol precipitation, the fragmented DNA was collected by centrifugation at $4^{\circ} \mathrm{C}$ and resuspended in hybridization buffer. The BeadChip was prepared for hybridization in a capillary flow-through chamber. Samples were applied to a BeadChip and divided by an IntelliHyb ${ }^{\circledR}$ seal. The loaded BeadChip was incubated overnight in the Illumina Hybridization Oven. The amplified and fragmented DNA samples anneal to locus-specific 50-mers (covalently linked to one of up to 300,000 bead types) during hybridization. Unhybridized and non-specifically hybridized DNA was washed away, and the BeadChip was prepared for staining and extension. BeadChip single-base extension of the oligo on the BeadChip, using the captured DNA as template, incorporates detectable labels on the BeadChip and determines the genotype call for the sample. Image captured and analysed on iScan System. The iScan Reader uses a laser to excite the fluor of the single-base extension product on the beads of the BeadChip. Light emissions from these fluors are then recorded in high-resolution images of the BeadChip. The data from these images were analyzed using Illumina's KaryoStudio Module. The microarray analysis showed deletion in the $22 q 11.21$ and gains in 8p23.2-23.3 \& 14q11.2 in both the twins. The twins were perfect match, excepting bigger size $(\sim 0.14 \mathrm{MB})$ of deletion in the second twin at 22q11.21 locus (Table 2).

\section{Discussion}

We report a pair of monozygotic twins with $22 \mathrm{q} 11.2$ microdeletion and the discordant phenotype. The second twin presented with the classical DiGeorge Syndrome whereas the first twin presented with developmental delay and mild dysmorphic features. We have tried to find out zygosity of the twins however as one of the twin was very sick and did not provide time to investigate, we were unable to provide absolute proof for the zygosity. However, genomic DNA analysis on Illumina Beadchip 300K microarray showed that twins 


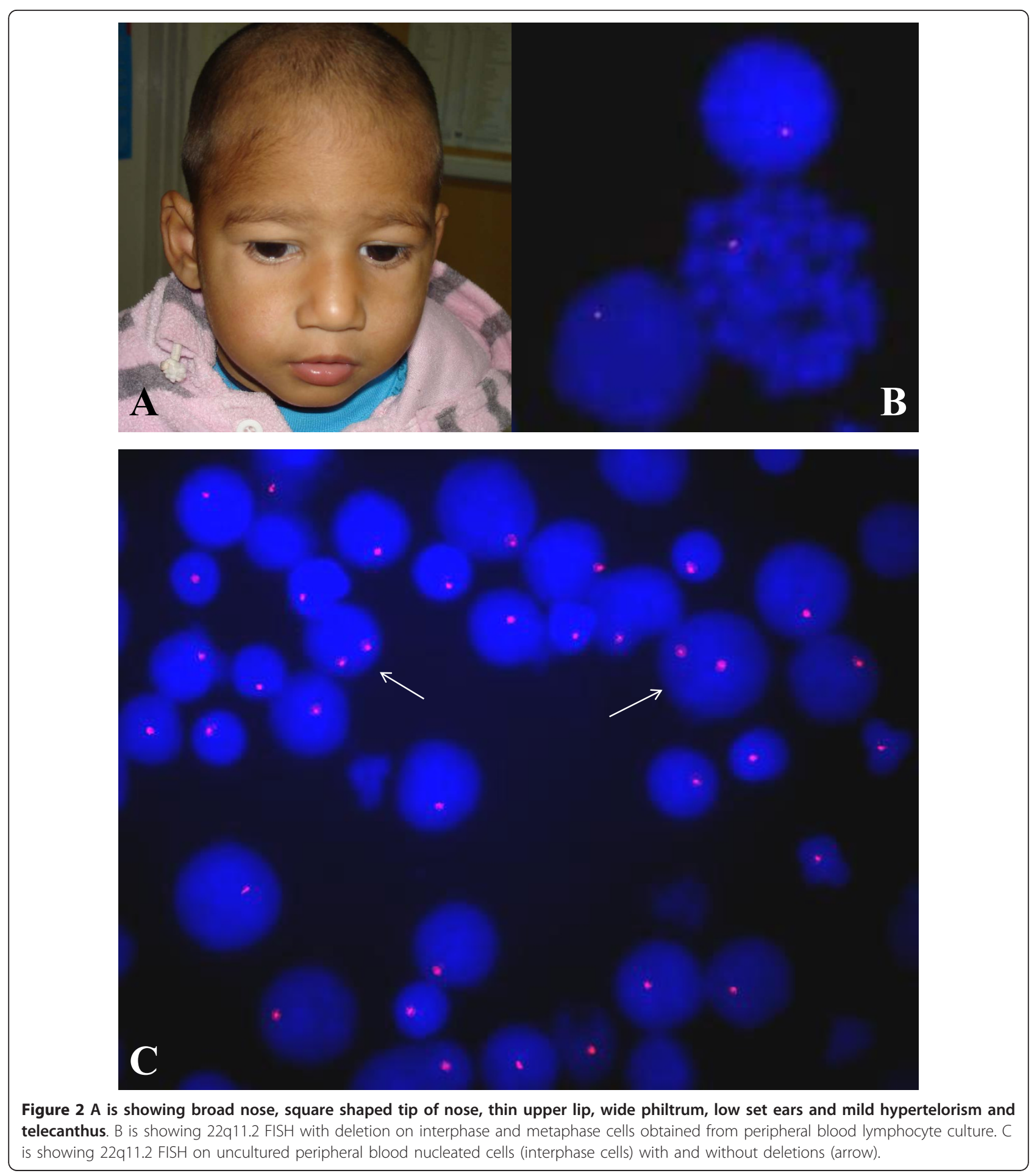

were perfect match except the size of 22q11.2 deletion. The microarray analysis and identical sex of the twins suggest that the twins were likely to be monozygotic. The twin research, in particular monozygotic, is a powerful tool for the study of discordances and testing hypotheses, particularly gene-environment interactions.
It is generally presumed that the monozygotic twins are genetically identical and that the phenotypic differences between twins are mainly due to environmental factors. However, the genetic and the epigenetic differences between the monozygotic twins have been described $[16,17]$. The phenotypic variability is well known with 
Table 2 is showing microarray results of twins

\begin{tabular}{|c|c|c|c|}
\hline Positive Findings & First Twin (Milder) & Second Twin (Severe) & Remarks \\
\hline Chromosome 8 & Gain & Gain & $8 p$ subtelomeric region \\
\hline Locus & p23.3-p23.2 & p23.3-p23.2 & First twin had larger size of gain (4880 bp) \\
\hline Start & 2190549 & 2190549 & No differences in numbers of genes \\
\hline End & 2480256 & 2475376 & \\
\hline Size $(\sim 0.3 \mathrm{MB})$ & 0289707 & 0284827 & \\
\hline Value & 3 & 3 & \\
\hline CNV Index & 0 & 0 & \\
\hline Number of Markers & 33 & 32 & \\
\hline Genes & 0 & 0 & \\
\hline Chromosome 14 & Gain & Gain & $14 q$ pericentromeric region \\
\hline Locus & $q 11.2$ & $q 11.2$ & Identical gain size \\
\hline Start & 19283777 & 19283777 & No differences in numbers of genes \\
\hline End & 19494891 & 19494891 & \\
\hline Size $((\sim 0.2 \mathrm{MB})$ & 00211114 & 00211114 & \\
\hline Value & 3 & 3 & \\
\hline CNV Index & 1 & 1 & \\
\hline Number of Markers & 14 & 14 & \\
\hline Genes & 6 & 6 & \\
\hline Chromosome 22 & Loss & Loss & DiGeorge syndrome 1 or Velocardiofacial \\
\hline Locus & $q 11.21$ & $q 11.21$ & syndrome \\
\hline Start & 17257787 & 17118296 & Second twin had large deletion \\
\hline End & 19792353 & 19792353 & (139491 bp; proximal deletion) \\
\hline Size $(>2.5 \mathrm{MB})$ & 2534566 & 2674057 & One gene more lost in second twin \\
\hline Value & 1 & 1 & (GGT3P) \\
\hline CNV Index & 2 & 2 & \\
\hline Number of Markers & 447 & 452 & \\
\hline Genes & $65^{*}$ & $66 \#$ & \\
\hline
\end{tabular}

* DGCR6; PRODH; KIAA1647; DGCR9; DGCR10; DGCR2; DGCR11; DGCR14; TSSK2; GSC2; SLC25A1; CLTCL1; HIRA; MRPL40; C22orf39; C22orf39; UFD1L; CDC45L; CLDN5; LOC150185; SEPT5; GP1BB; TBX1; GNB1L; C22orf29; TXNRD2; COMT; COMT; COMT; COMT; ARVCF; C22orf25; MIR185; DGCR8; MIR1306; TRMT2A; RANBP1; ZDHHC8; LOC150197; RTN4R; MIR1286; DGCR6L; LOC375133; RIMBP3; ZNF74; SCARF2; KLHL22; MED15; POM121L4P; TMEM191A; PI4KA; SERPIND1; SNAP29; CRKL; AIFM3; AIFM3; LZTR1; THAP7; FLJ39582; MGC16703; P2RX6; P2RX6; SLC7A4; P2RX6P; LOC400891 (First Twin)

\# GGT3P; DGCR6; PRODH; KIAA1647; DGCR9; DGCR10; DGCR2; DGCR11; DGCR14; TSSK2; GSC2; SLC25A1; CLTCL1; HIRA; MRPL40; C22orf39; C22orf39; UFD1L; CDC45L; CLDN5; LOC150185; SEPT5; GP1BB; TBX1; GNB1L; C22orf29; TXNRD2; COMT; COMT; COMT; COMT; ARVCF; C22orf25; MIR185; DGCR8; MIR1306; TRMT2A; RANBP1; ZDHHC8; LOC150197; RTN4R; MIR1286; DGCR6L; LOC375133; RIMBP3; ZNF74; SCARF2; KLHL22; MED15; POM121L4P; TMEM191A; PI4KA; SERPIND1; SNAP29; CRKL; AIFM3; AIFM3; LZTR1; THAP7; FLJ39582; MGC16703; P2RX6; P2RX6; SLC7A4; P2RX6P; LOC400891 (Second Twin)

the 22q11.2 microdeletion syndrome across unrelated, related or twins [7,18-21]. The phenotypic variability is also reported in the monozygotic twins repeatedly [6-12]. The frequent observation of variability of clinical symptoms with the 22q11.2 microdeletion in the monozygotic twins suggests underlying scientific reasons. The reasons for the phenotypic variability in the monozygotic twins could be due to various mechanisms such as the differences in size of deletion, somatic mosaicism, differences in copy number variations (CNV), differences in epigenetic changes, differences in modifying genetic factors, differences in intrauterine environment or twinning process itself.

Our likely explanation for the discordant phenotype is the differences in the size of the deletion between the twins. We have found a difference of $0.14 \mathrm{MB}$ size between the twins. Although the differences in size of the deletion between monozygotic twins is unlikely however this may be possible with this syndrome as 22q11.2 locus contains several (at least eight) low copy repeat (LCR) DNA segments of more than $95 \%$ sequence homology [22]. The LCR (long stretches of repeated DNA sequence) makes the DNA unstable through non-allelic homologous recombination during cell division. The LCR take part in a homologous recombination involving unequal inter and intrachromosomal crossover, either in the meiosis or in the mitosis. This recombination leads to DNA loss or gains, thus the size of the deletion. The literatures on the differences in the size of 22q11.2 microdeletion with the phenotypic difference are contradictory, some agree [23] whereas others disagree [18,20,24-26]. Our DNA microarray analysis data showed altered size of the deletion between the twins, about 0.14 MB bigger deletion in the second 
twin with more severe presentation. This small difference in size of the deletion was not expected to be detectable by the FISH. Hence, we may conclude that most of the negative studies on size using FISH $[18,20,24-26]$ may not be correct. The difference in the size with the phenotypic discordance was observed with other microdeletion syndromes viz., Yq microdeletion [27], Wolf-Hirschhorn Syndrome [28], etc. Our microarray analysis found deletion in $22 \mathrm{q} 11.21$ in both the twins, except the bigger size $(\sim 0.14 \mathrm{MB})$ of the deletion containing GGT3P gene (gamma-glutamyltransferase 3 pseudogene) in the second twin. The GGT3P gene initiates extracellular glutathione breakdown and catalyzes the transfer of the glutamyl moiety of glutathione to amino acids/dipeptide acceptors. The GGT3P gene increases ceruloplasmin and oxidase activity. Whether this has any role with cardiac development is yet to be linked. Thus genotypic differences i.e., the size of the deletion may be likely explanation for the phenotypic differences. The early post zygotic event could have been played a role in the alteration of 22q11.2 deletion size and, thus the phenotypic variability in the monozygotic twins.

Other possible explanation for the discordant phenotype in the monozygotic twins is the somatic mosaicism $[29,30]$, particularly in the first twin with milder phenotype. Somatic mosaicism is usually defined by the presence of genetically distinct populations of somatic cells in an organism. Any genetic difference between the monozygotic twins represents an extreme example of the somatic mosaicism. This can result in a milder disease phenotype. The somatic mosaicism for pathogenesis may be seen as a rule rather than exception. We evaluated for mosaicism by interphase FISH by examining large number of cells and found no evidence of mosaicism in all three types of tissues (blood i.e., mesoderm, buccal i.e., ectoderm and urinary cells i.e., endoderm) in the first twin who had milder phenotype. The second twin with classic 22q11.2 microdeletion syndrome displayed approximately $92 \%$ interphase cells with 22q11.2 hemizygous deletion in blood cells. The first twin with milder phenotype displayed approximately $94 \%$ interphase cells with 22q11.2 hemizygous deletion (uncultured blood, buccal \& urinary cells; Table 1). All the metaphase cells displayed 22q11.2 hemizygous deletion in both the twins. Thus, the mosaicism as underlying etiology for the twin discordance was ruled out.

The other explanation for the discordant phenotype could be the differences in the structural variations in genome. An important development in human genetics is the discovery of substantial large-scale structural variation changing the chromosomal architecture (such as deletions, duplications, insertions, inversions, and more complex rearrangements) and occurring both in phenotypically normal as well as abnormal subjects. The most explored subtype of structural variation involves changes affecting copy number of DNA segments (denoted as copy number variation or $\mathrm{CNV}$ ), often involving fragments of chromosomes that are considerable in size. In recent years genomic studies using microarray platform provides genomic explanation (CNV) for phenotypic discordance in the monozygotic twins in schizophrenia [31,32], parkinsonism/dementia [10], etc. It is now well known that the monozygotic twins have CNV leading to differences in the phenotype $[10,33]$. The CNV have shown to confer increased risk for the congenital cardiovascular disorders such as the tetralogy of Fallot [33]. Similarly, in a mice experiment with low copy transgenic manifest ear disorders only, while the mice with high copy transgenic presents with reduced viability and multiple anomalies that were similar to humans VCFS/DGS [34]. Our microarray analysis did not find any discordance related to the CNV between the twins.

The discordant phenotype could also be due to the differences in the epigenome [7]. The epigenomic changes (e.g., DNA methylation) are able to influence the expression of the gene without affecting the DNA sequence. The methylation of genomic DNA may affect a variety of processes related to gene expression including imprinting, chromosome inactivation and gene silencing. Given the variety of developmental anomalies associated with 22q11 deletions, it is logical to implicate a methylation difference between the twins that would alter the expression of some/most genes of this region. We are unable to comment on this hypothesis at this time due to various technical difficulties.

The discordant phenotype could also be due to the early post zygotic second hit (mutation) in modifying genetic factors (e.g., fgf8 at 10q24, fgf10 at 5p12-p13, Gbx2 at $2 \mathrm{q} 37$, Pitx2 at $4 \mathrm{q} 25$, Vgef at $6 \mathrm{p} 21.3$, Tgf $\beta$ at 1p34.1; Chordin at 3q27, Sonic hedgehog at 7q36, etc) in one of the twins [9,35-40]. The second hit (mutation) hypothesis may entail a variety of mutational mechanisms including replication errors, base changes and additional deletions involving LCR and Alu repeats of the region. The second somatic hit hypothesis, however, need not be restricted to the genetic changes at the level of the DNA sequence but it may also involve the epigenetic changes. Stalmans et al [36] provided evidence that variation in the gene encoding vascular endothelial growth factor may modify the cardiovascular phenotype with hemizygous for the 22q11.2 deletion. Similarly, Driscoll et al [37] reported modifiers for palatal phenotypes with this syndrome. It is known that the genetic background influences the penetrance of cardiovascular, thymic, and parathyroid anomalies in the mice [38,39]. Girirajan et al [41] proposed a 'two-hit' model, 
wherein a secondary insult is necessary during development to result in a more severe clinical manifestation. The second hit could potentially be another CNV, a disruptive single-base-pair mutation in a phenotypically related gene or an environmental event that influences the phenotype or altered deletion size as with our twins. The two-hit model also helps to explain the underlying phenotypic variability reported for several recurrent microdeletions. The majority of second hits are probably not detectable even by very high-resolution arrays. Whole-genome re-sequencing may reveal a surprising number of additional contributing loci.

Finally, the intrauterine environment or the twinning process [11] itself, and non-genetic factors [42] may influence phenotypic discordance. The twinning process imposes a growth disadvantage that may be more severe in one [8] thus may account for the discordance of malformations in the twin pairs. Other influences of the twinning process, which cause discordant cardiovascular anomalies include the disturbance of laterality and the placental vascular anastomoses.

We conclude that altered size of the deletion may likely be the underlying etiology for the discordance in the phenotype in our monozygotic twins. We think early post zygotic mitotic non-allelic homologous recombination could have been played a role in the alteration of the size of 22q11.2 deletion and, thus the phenotypic variability.

\section{Consent}

Written informed consent was obtained from the parents of patients for publication of cases and accompanying images. A copy of the written consent is available for review by the Editor-in-Chief of this journal (additional file 1).

\section{Additional material}

Additional file 1: Consent of parents. Consent for permission of using photograph, clinical \& other information for publication.

\begin{abstract}
Acknowledgements
The study was supported by grant from Indian Council of Medical Research, New Delhi, India. We thank Department of Paediatrics of All India Institute of Medical Sciences, New Delhi, India for providing clinical management to the cases. We also thank the family members for their invaluable co-operation during the study. We are grateful to Professor Mariano Rocchi (University of Bari, Italy) for providing molecular probes (PAC/BAC clones for 22q11.2 locus) for the study. We also thank the Centre for Genomic Application, New Delhi for helping in microarray analysis.
\end{abstract}

\section{Author details}

'Department of Reproductive Biology, All India Institute of Medical Sciences, New Delhi, India. ${ }^{2}$ The Centre for Genomic Application, 254 Okhla Industrial Area Phase III, New Delhi, India.

\section{Authors' contributions}

$\mathrm{AH}$ formulated activity plan, checked \& interpreted results, besides being the Principal investigator of the project funded by Indian Council of Medical Research, India. He also reviewed clinical findings, prepared manuscript and responded to the queries of reviewers. He is the guarantor of the manuscript. MJ carried out all FISH related activity under guidance of $\mathrm{AH}$, besides working as Research fellow for the project under $\mathrm{AH}$. IC also carried out FISH related activity under guidance of $\mathrm{AH}$. BV was involved in microarray analysis \& interpretation of microarray data. All authors read and approved final manuscript.

\section{Competing interests}

The authors declare that they have no competing interests.

Received: 23 November 2011 Accepted: 13 March 2012

Published: 13 March 2012

\section{References}

1. Oskarsdottir S, Vujic M, Fasth A: Incidence and prevalence of the 22q11 deletion syndrome: A population-based study in Western Sweden. Arch Dis Child 2004, 89:148-151.

2. Devriendt K, Fryns J-P, Mortier G, Van Thienen M-N, Keymolen K: The annual incidence of DiGeorge/velocardiofacial syndrome. J Med Genet 1998, 35:789-790.

3. DuMontcel ST, Mendizabal H, Ayme S, Levy A, Philip N: Prevalence of 22q11 microdeletion. J Med Genet 1996, 33(8):719.

4. Goldmuntz E, Clark BJ, Mitchell LE, Jawad AF, Cuneo BF, Reed L, McDonaldMcGinn D, Chien P, Feuer J, Zackai EH, Emanuel BS, Driscoll DA: Frequency of 22q11 deletions in patients with conotrucal defects. J Am Coll Cardiol 1998, 32:492-498.

5. Robin NH, Shprintzen RJ: Defining the clinical spectrum of deletion 22q11.2. J Pediatr 2005, 147:90-96.

6. Hillebrand G, Siebert R, Simeoni E, Santer R: DiGeorge syndrome with discordant phenotype in monozygotic twins. J Med Genet 2000, 37:e23.

7. Singh SM, Murphy B, O'Reilly R: Monozygotic twins with chromosome $22 q 11$ deletion and discordant phenotypes: updates with an epigenetic hypothesis. J Med Genet 2002, 39:e71.

8. Goodship J, Cross I, Scambler P, Burn J: Monozygotic twins with chromosome 22q1 1 deletion and discordant phenotype. J Med Genet 1995, 32:746-748.

9. Hatchwell E: Monozygotic twins with chromosome $22 q 11$ deletion and discordant phenotype. J Med Genet 1996, 33(9):746-748.

10. Bruder CE, Piotrowski A, Gijsbers AA, Andersson R, Erickson S, Diaz de Ståhl T, Menzel U, Sandgren J, von Tell D, Poplawski A, Crowley M, Crasto C, Partridge EC, Tiwari H, Allison DB, Komorowski J, van Ommen GJ, Boomsma DI, Pedersen NL, den Dunnen JT, Wirdefeldt K, Dumanski JP: Phenotypically Concordant and Discordant Monozygotic Twins Display Different DNA Copy-Number-Variation Profiles. Am J Hum Genet 2008, 82(3):763-771

11. Fryer A: Monozygotic twins with 22qll deletion and discordant phenotypes. J Med Genet 1996, 33(2):173.

12. Lu JH, Chung MY, Hwang B, Chien HP: Monozygotic Twins with Chromosome 22q11 Microdeletion and Discordant Phenotypes in Cardiovascular Patterning. Pediatr Cardiol 2001, 22:260-263.

13. Halder A, Jain M, Kabra M, Gupta N: 22q11.2 Mosaic 22q11.2 microdeletion syndrome: diagnosis and clinical manifestations of two cases. Molecular Cytogenetics 2008, 1:18.

14. Halder A, Jain M, Chaudhary I, Kabra M: Prevalence of $22 q 11.2$ microdeletion in 146 patients with cardiac malformation in a referral hospital of North India. BMC Medical Genetics 2010, 11:101.

15. Halder A, Fauzdar A: Potential use of blood, buccal and urine cells for rapid noninvasive diagnosis of suspected aneuploidy using FISH. Journal of Clinical \& Diagnostic Research 2007, 1(2):33-38, Available from http:// www.jcdr.net/back_issues.asp?issn=0973 709x\&year=2007\&month=April\&volume=1\&issue=2\&page=33-38\&id=51.

16. Gringras $P, C$ Chen $W$ : Mechanisms for differences in monozygous twins. Early Hum Dev 2001, 64:105-117.

17. Fraga MF, Ballestar E, Paz MF, Ropero S, Setien F, Ballestar ML, HeineSuñer D, Cigudosa JC, Urioste M, Benitez J, Boix-Chornet M, SanchezAguilera A, Ling C, Carlsson E, Poulsen P, Vaag A, Stephan Z, Spector TD, 
Wu YZ, Plass C, Esteller M: Epigenetic differences arise during the lifetime of monozygotic twins. Proc Natl Acad Sci USA 2005, 102:10604-10609.

18. Desmaze C, Scambler P, Prieur M, Halford S, Sidi D, Le Deist F, Aurias A: Routine diagnosis of DiGeorge syndrome by fluorescent in situ hybridisation. Hum Genet 1993, 90:663-665.

19. McLean SD, Saal HM, Spinner NB, Emanuel BS, Driscoll DA: Velo-cardiofacial syndrome. Intrafamilial variability of the phenotype. Am J Dis Child 1993, 147:1212-1216.

20. Scambler PJ, Carey AH, Wyse RKH, Roach S, Dumanski JP, Nordenskjold M, Williamson R: Microdeletions within 22q11 associated with sporadic and familial Di-George syndromes. Genomics 1991, 10:201-206.

21. Van Hemel JO, Schaap C, Van Opstal D, Mulder MP, Niermeijer MF, Meijers JHC: Recurrence of DiGeorge syndrome: prenatal detection by FISH of a molecular 22q11 deletion. J Med Genet 1995, 32:657-658.

22. Gotter AL, Shaikh TH, Budarf ML, Rhodes CH, Emanuel BS: A palindromemediated mechanism distinguishes translocations involving LCR-B of chromosome 22q11.2. Hum Mol Genet 2004, 13:103-115.

23. Rauch A, Zink S, Zweier C, Thiel CT, Koch A, Rauch R, Lascorz J, Hüffmeier U, Weyand M, Singer H, Hofbeck M: Systematic assessment of atypical deletions reveals genotype-phenotype correlation in 22q11.2. J Med Genet 2005, 42:871-876.

24. Sandrin-Garcia P, Abramides DV, Martelli LR, Ramos ES, Richieri-Costa A, Passos GA: Typical phenotypic spectrum of velocardiofacial syndrome occurs independently of deletion size in chromosome 22q11.2. Mol Cell Biochem 2007, 303:9-17.

25. Carlson C, Sirotkin H, Pandita R, Goldberg R, McKie J, Wadey R, Patanjali SR, Weissman SM, Anyane-Yeboa K, Warburton D, Scambler P, Shprintzen R, Kucherlapati R, Morrow BE: Molecular definition of 22q11 deletion in 151 velo-cardio-facial syndrome patients. Am J Med Genet 1997, 61:620-629.

26. Morrow B, Goldberg R, Carlson C, Das Gupta R, Sirotkin H, Collins J, Dunham I, O'Donnell H, Scambler P, Shprintzen R, Kucherlapati R: Molecular definition of the 22q11 deletions in velo-cardio-facial syndrome. Am J Hum Genet 1995, 56:1391-1403.

27. Stuppia L, Calabrese G, Franchi PG, Mingarelli R, Gatta V, Palka G, Dallapiccola B: Widening of a Y Chromosome Interval-6 Deletion Transmitted from a Father to his infertile Son Accounts for an oligozoospermia Critical Region Distal to the RBM1 and DAZ Genes. Am J Hum Genet 1996, 59:1393-1395.

28. Zollino M, Stefano CD, Zampino G, Mastroiacovo P, Wright TJ, Sorge G, Selicorni A, Tenconi R, Zappala A, Battaglia A, Rocco MD, Palka G, Pallotta R, Altherr MR, Neri G: Genotype-Phenotype Correlations and Clinical Diagnostic Criteria in Wolf-Hirschhorn Syndrome. Am J Med Genet 2000, 94(3):254-261.

29. Kehrer-Sawatzki H, Kluwe L, Sandig C, Kohn M, Wimmer K, Krammer U, Peyrl A, Jenne DE, Hansmann I, Mautner VF: High Frequency of Mosaicism among Patients with Neurofibromatosis Type 1 (NF1) with Microdeletions Caused by Somatic Recombination of the JJAZ1 Gene. Am J Hum Genet 2004, 75:410-423.

30. Youssoufian $\mathrm{H}$, Pyeritz RE: Mechanisms and consequences of somatic mosaicism in humans. Nat Rev Genet 2002, 3:748-758.

31. Tsujita T, Niikawa N, Yamashita H, Imamura A, Hamada A, Nakane Y, Okazaki Y: Genomic Discordance Between Monozygotic Twins Discordant for Schizophrenia. Am J Psychiatry 1998, 155:422-424.

32. Maiti S, Kumar KHBG, Castellani CA, O'Reilly R, Singh SM: Ontogenetic De Novo Copy Number Variations (CNVs) as a Source of Genetic Individuality: Studies on Two Families with MZD Twins for Schizophrenia. PLOS ONE 2011, 6:e17125.

33. Greenway SC, Pereira AC, Lin JC, DePalma SR, Israel SJ, Mesquita SM, Ergul E, Conta JH, Korn JM, McCarroll SA, Gorham JM, Gabriel S, Altshuler DM, Quintanilla-Dieck Mde L, Artunduaga MA, Eavey RD, Plenge RM, Shadick NA, Weinblatt ME, De Jager PL, Hafler DA, Breitbart RE, Seidman JG, Seidman CE: De novo copy number variants identify new genes and loci in isolated sporadic tetralogy of Fallot. Nat Genet 2009, 41:931-935.

34. Liao J, Kochilas L, Nowotschin S, Arnold JS, Aggarwal VS, Epstein JA, Brown MC, Adams J, Morrow BE: Full spectrum of malformations in velocardio-facial syndrome/DiGeorge syndrome mouse models by altering Tbx1 dosage. Human Molecular Genetics 2004, 13:1577-1585.

35. Crosby JL, Vamum DS, Nadeau JH: Two-hit model for sporadic congenital anomalies in mice with the disorganization mutation. Hum Genet 1993, 52:866-874.
36. Stalmans I, Lambrechts $D$, De Smet $F$, Jansen $S$, Wang J, Maity $S$, Kneer $P$, von der Ohe M, Swillen A, Maes C, Gewillig M, Molin DG, Hellings P, Boetel T, Haardt M, Compernolle V, Dewerchin M, Plaisance S, Vlietinck R, Emanuel B, Gittenberger-de Groot AC, Scambler P, Morrow B, Driscol DA, Moons L, Esguerra CV, Carmeliet G, Behn-Krappa A, Devriendt K, Collen D, Conway SJ, Carmeliet P: VEGF: a modifier of the del22q11 (DiGeorge) syndrome? Nat Med 2003, 9:173-182.

37. Driscoll DA, Boland T, Emanuel BS, Kirschner RE, LaRossa D, Manson J, McDonald-McGinn D, Randall P, Solot C, Zackai E, Mitchell LE: Evaluation of Potential Modifiers of the Palatal Phenotype in the 22q11.2 Deletion Syndrome. Cleft Palate-Craniofacial Journal 2006, 43:435-441.

38. Taddei I, Morishima M, Huynh T, Lindsay EA: Genetic factors are major determinants of phenotypic variability in a mouse model of the DiGeorge/del22q11 syndromes. Proc Natl Acad Sci 2001, 98:11428-11431.

39. Aggarwal VS, Morrow BE: Genetic modifiers of Velo- cardio- facial syndrome/DiGeorge Syndrome. Dev Disabil Res Rev 2008, 14:19.

40. Rauch A, Pfeiffer RA, Leipold G, Singer H, Tigges M, Hofbeck M: A Novel 22q11.2 Microdeletion in Digeorge Syndrome. Am J Hum Genet 1999, 64:659-667.

41. Girirajan S, Rosenfeld JA, Cooper GM, Antonacci F, Siswara P, Itsara A, Vives L, Walsh T, McCarthy SE, Baker C, Mefford HC, Kidd JM, Browning SR, Browning BL, Dickel DE, Levy DL, Ballif BC, Platky K, Farber DM, Gowans GC, Wetherbee JJ, Asamoah A, Weaver DD, Mark PR, Dickerson J, Garg BP, Ellingwood SA, Smith R, Banks VC, Smith W, McDonald MT, Hoo JJ, French BN, Hudson C, Johnson JP, Ozmore JR, Moeschler JB, Surti U, Escobar LF, El-Khechen D, Gorski JL, Kussmann J, Salbert B, Lacassie Y, Biser A, McDonald-McGinn DM, Zackai EH, Deardorff MA, Shaikh TH, Haan E, Friend KL, Fichera M, Romano C, Gécz J, DeLisi LE, Sebat J, King MC, Shaffer LG, Eichler EE: A recurrent 16p12.1 microdeletion supports a twohit model for severe developmental delay. Nature Genetics 2010, 42:203-210.

42. Ryan AK, Goodship JA, Wilson DI, Philip N, Levy A, Seidel $H_{\text {, }}$ Schuffenhauer S, Oechsler H, Belohradsky B, Prieur M, Aurias A, Raymond FL, Clayton-Smith J, Hatchwell E, McKeown C, Beemer FA, Dallapiccola B, Novelli G, Hurst JA, Ignatius J, Green JA, Winter RM, Brueton L, Brøndum-Nielsen L, Stewart F, Van Essen T, Patton M, Paterson J, Scambler PJ: Spectrum of clinical features associated with interstitial chromosome 22q11 deletions: a European collaborative study. J Med Genet 1997, 34:798-804.

doi:10.1186/1755-8166-5-13

Cite this article as: Halder et al:: Chromosome 22q11.2 microdeletion in monozygotic twins with discordant phenotype and deletion size. Molecular Cytogenetics 2012 5:13.

\section{Submit your next manuscript to BioMed Central and take full advantage of:}

- Convenient online submission

- Thorough peer review

- No space constraints or color figure charges

- Immediate publication on acceptance

- Inclusion in PubMed, CAS, Scopus and Google Scholar

- Research which is freely available for redistribution

Submit your manuscript at www.biomedcentral.com/submit
C Biomed Central 